\title{
FAKTOR YANG MEMPENGARUHI LOYALITAS PETERNAK PLASMA DALAM KEMITRAAN USAHA TERNAK AYAM RAS PEDAGING/BROILER RAYON YOGYAKARTA (Kasus di Kemitraan PT. Malindo Feedmill Cabang Yogyakarta)
}

\author{
Maria Pinkan Elionora Sepoetri ${ }^{1)}$, Heru Irianto ${ }^{1)}$, Nuning Setyowati ${ }^{1)}$ \\ ${ }^{1)}$ Program Studi Agribisnis, Fakultas Pertanian, Universitas Sebelas Maret Surakarta \\ Jl.Ir.Sutami No.36 A Kentingan Surakarta 57126 Telp./Fax (0271) 637457 \\ Email: margarethaelionora@gmail.com
}

\begin{abstract}
This research aims to know the implementation of the ongoing partnerships in PT Malindo Feedmill branch Yogyakarta, knowing the influence of variable quality of products, service quality, breeder expectation, and corporate image towards the breeders satisfaction, as well as knowing the influence breeders satisfaction towards breeder loyalty. This research uses the basic method of descriptive analytic. This research was carried out at PT. Malindo Feedmill branch Yogyakarta. The method of determining the location of the research done by the purposive method and method of determination of samples is carried out by the census method by the number of samples of 75 respondents. The technique of collecting data through observation, interviews, and questionnaires that have been tested for validity and reliability. The analysis of the data used in this research is a method of Structural Equation Models (SEM) with an alternative method of Partial Least Square (PLS). The results showed that: (1) Partnership patterns in PT Malindo Feedmill. is a core-plasma pattern with a strategy of 'win-win solution', there is a cooperation agreement between the breeders and the company. (2) The product quality does not affect toward breeders satisfaction. (3) The service quality, the breeders expectation and corporate image has a positive influence toward breeders satisfaction.

(4) The breeders satisfaction has a positive influence toward breeders loyalty.
\end{abstract}

Keywords: Breeders Satisfaction, Core-Plasma Partnership, Loyalty, Partial Least Square (PLS), Stuctural Equation Model (SEM)

\section{PENDAHULUAN}

Pembangunan subsektor peternakan merupakan bagian dari pembangunan sektor pertanian yang memiliki nilai strategis, yang mampu meningkatkan optimalisasi pemanfaatan lahan usaha tani dan adanya perubahan cara pemanfaatan lahan usaha tani bagi petani di lahan usaha, yaitu usaha ternak. Usaha peternakan merupakan suatu usaha yang dapat diandalkan untuk memenuhi kebutuhan hidup keluarga dan alat kontribusi bagi ketahanan pangan, salah satunya adalah usaha ternak ayam pedaging/Broiler yang memiliki prospek dalam dunia bisnis. Prospek dalam dunia bisnis dan perdagangan dapat dilihat dari tingginya konsumsi masyarakat terhadap daging ayam menyebabkan peningkatan produksi dari tahun ke tahun. Berdasarkan data dari Badan Pusat Statistik Indonesia Tahun 2015, jumlah produksi daging ayam Broiler selama empat tahun, dari tahun 2012 sampai dengan tahun 2015 mengalami peningkatan dari tahun ke tahun. Berturutturut, pada tahun 2012 ber-jumlah 1.400.468 ton, tahun 2013 berjumlah 1.497.876 ton, tahun 2014 berjumlah 1.544 .378 ton, dan terakhir pada tahun 2015 berjumlah 1.627.107 ton. Peningkatan jumlah produksi naik sekitar 50.000 sampai 100.000 ton per tahun. Peningkatan jumlah produksi daging ayam diikuti dengan tingginya konsumsi masyarakat Indonesia akan daging ayam untuk pemenuhan protein hewani.

Salah satu cara untuk meningkatkan produksi ayam broiler yaitu dengan pola kemitraan (Priyono, Nufus, dan Dessy, 2004). Kemitraan merupakan suatu bentuk jalinan kerja sama dari dua atau lebih pelaku usaha yang saling menguntungkan. Salah satu perusahaan besar yang menawarkan sistem kemitraan adalah PT. Malindo Feedmill, yang menerapkan pola kemitraan inti-plasma. Dimana perusahaan berperan sebagai inti yang 
menyediakan sapronak (DOC, pakan, obat dan vaksin) serta bimbingan teknis, kemudian peternak sebagai plasma yang wajib menyediakan kandang dan tenaga produksi.

Kemitraan yang ditawarkan oleh setiap perusahaan inti memiliki kelebihan dan kekurangan masing-masing. Hal tersebut menimbulkan persaingan antar perusahaan dalam mendapatkan dan mempertahankan loyalitas peternak. Loyalitas peternak didapat dari kepuasan peternak selama bermitra. Kepuasan peternak dapat dilihat dari kepuasan-nya akan produk, pelayanan, kesesuaian dengan harapan peternak, serta citra dari perusahaan inti. Kepuasan peternak plasma terhadap perusahaan inti dapat berdampak yang positif, karena peternak cenderung loyal dan tidak akan mencari perusahaan kemitraan lain. Begitupun sebaliknya, apabila peternak plasma merasa tidak puas terhadap kinerja dan pelayanan yang diberikan inti, peternak plasma diduga akan mencari perusahaan yang memberikan kinerja yang lebih baik.

Penelitian ini bertujuan untuk mendeskripsikan pelaksanaan kemitraan yang sedang dijalankan oleh PT. Malindo Feedmill Cabang Yogyakarta; menganalisisis pengaruh dari kualitas produk, kualitas pelayanan, harapan peternak, dan citra perusahaan terhadap kepuasan peternak; serta menganalisis pengaruh kepuasan peternak terhadap loyalitas peternak. Hipotesis yang diajukan dalam penelitian ini antara lain: H1 (kualitas produk berpengaruh positif terhadap kepuasan peternak), H2 (kualitas pelayanan berpengaruh positif terhadap kepuasan peternak), H3 (harapan peternak berpengaruh positif terhadap kepuasan peternak), H4 (citra perusahaan berpengaruh positif terhadap kepuasan peternak), dan H5 (kepuasan peternak berpengaruh positif terhadap loyalitas).

\section{METODE PENELITIAN}

Metode dasar yang digunakan dalam penelitian ini adalah metode deskripsi analitis. Bertujuan memperoleh penjelasan objektif mengenai faktor yang mempengaruhi kepuasan peternak plasma ayam Broiler terhadap loyalitasnya dalam menjalankan kemitraan dengan PT. Malindo Feedmill. Teknik penelitian yang digunakan dalam penelitian ini adalah teknik survey, dengan cara mengum-pulkan data dimana peneliti atau pengumpul data mengajukan pertanyaan secara lisan maupun secara tertulis denganbantuan kuesioner (Sanusi, 2011).

Penentuan lokasi penelitian dilakukan secara purposive (sengaja), yaitu secara sengaja berdasarkan pertimbangan tertentu bahwa PT. Malindo Feedmill Cabang Yogyakarta merupakan perusahaan yang menawarkan kemitran. PT. Malindo Feedmill juga memiliki cakupan daerah yang cukup luas untuk populasi peternak plasma. Penelitian ini dilaukan selama satu bulan dalam bulan Juni 2016 di lima daerah yang termasuk cakupan area Yogyakarta menurut PT. Malindo Feedmill, yaitu Sleman, Magelang, Gunung Kidul, Bantul, dan Kulonprogo. Responden penelitian ini adalah 2 orang karyawan/ manager PT. Malindo Feedmill dan 75 orang peternak plasma yang diambil secara sensus (semua populasi dijadikan sampel).

Variabel penelitian yang digunakan adalah variabel eksogen (Kualitas Produk, Kualitas Pelayanan, Harapan Peternak, dan Citra Perusahaan) dan variabel endogen (Kepuasan Peternak dan Loyalitas). Variabel yang digunakan dalam penelitian ini menggunakan variabel observed atau variabel teramati sebagai indikator sebanyak 22 indikator dan variabel laten sebanyak 6 variabel dengan menggunakan skala Likert $1-5$.

Metode analisis pengaruh kepuasan peternak terhadap loyalitas menggunakan metode alternatif dari Structural Equation Modelling (SEM), yaitu metode Partial Least Squre (PLS). Tujuan PLS adalah untuk analisis prediksi dalam situasi kompleksitas yang tinggi dan dukungan teori yang rendah, tidak mengasumsikan data harus dengan pengukuran skala tertentu, dapat diterapkan pada semua skala data, tidak membutuhkan banyak asumsi dan ukuran sample tidak harus besar (Ghozali, 2008). Analisis ini akan diawali dengan pengujian instrumen penelitian (uji validitas dan reliabilitas). Kemudian akan dilanjutkan dengan pengujian menggunakan PLS yang akan dilakukan pengujian model pengukuran (outer model) dan pengujian model struktural (inner model), serta dilanjutkan dengan pengujian hipotesa menggunakan metode bootstrapping. Model penelitian dapat dilihat pada gambar1. 


\section{HASIL DAN PEMBAHASAN}

\section{Gambaran Umum Lokasi Penelitian}

PT. Malindo Feedmill merupakan perusahaan yang bergerak dalam bisnis pakan ternak, pembibitan ayam, peternakan ayam pedaging, serta makanan olahan yang berpusat di Jakarta. PT. Malindo Feedmill didirikan pada tanggal 10 Juni 1997. Pada tahun 2000, perusahaan mulai memasuki bisnis produksi pakan ternak di Indonesia. Pada tahun 2001, perusahaan mendirikan entitas anak yaitu yaitu PT. Bibit Indonesia. PT. Malindo Feedmill menempatkan perusahaan untuk "go public" dan mencatatkan sahamnya untuk pertama kali di Bursa Efek Jakarta pada tahun 2006. Pada tahun 2007, mendirikan PT. Prima Fajar sebagai entitas anak perusahaan yang bergerak dalam bisnis ayam pedaging melalui kemitraan. Perusahaan membangun pabrik pakan baru pada tahun 2008. Pada tahun 2013, perusahaan memulai bisnis pengolahan makanan melalui anak perusahaan PT. Malindo Food Delight. Pada tahun 2015, perusahaan telah mendapatkan izin ekspor makanan olahan ke Jepang.

\section{Sistem Kemitraan PT. Malindo Feedmill}

Kemitraan yang dijalankan oleh PT. Malindo Feedmill dengan peternak plasma selain untuk memperoleh profit juga bertujuan untuk membantu dalam swasembada pangan dengan menciptakan ketahanan pangan dalam pemenuhan protein masyarakat Indonesia lewat komoditas unggas ayam pedaging. Tujuan tersebut dijelaskan dalam visi dan misi PT. Malindo Feedmill dalam menjalankan kemitraan. PT. Malindo Feedmill menggunakan strategi 'win-win solution' di dalam menjalankan kemitraan dengan peternak plasma. PT. Malindo Feedmill mengharapkan tidak ada peternak yang merasa dirugikan lewat kerjasama usaha yang ditawarkan, begitupun sebaliknya.

\section{Mekanisme Pelaksanaan Kemitraan di PT. Malindo Feedmill}

Pelaksanaan sistem kemitraan antara PT. Malindo Feedmill dengan peternak plasma diawali oleh pihak perusahaan inti dengan mengadakan sosialisasi kepada peternak atau pendekatan personal ke peternak mengenai kemitraan. Peternak yang tertarik untuk bekerjasama dengan perusahaan inti akan mendaftar dan mengisi form yang diberikan perusahaan juga dengan membawa syarat yang sudah ditentukan perusahaan inti. Setelah form dan data peternak masuk ke perusahaan, perusahaan cabang melakukan survey kandang dan kondisi peternak, setelah itu perusahaan

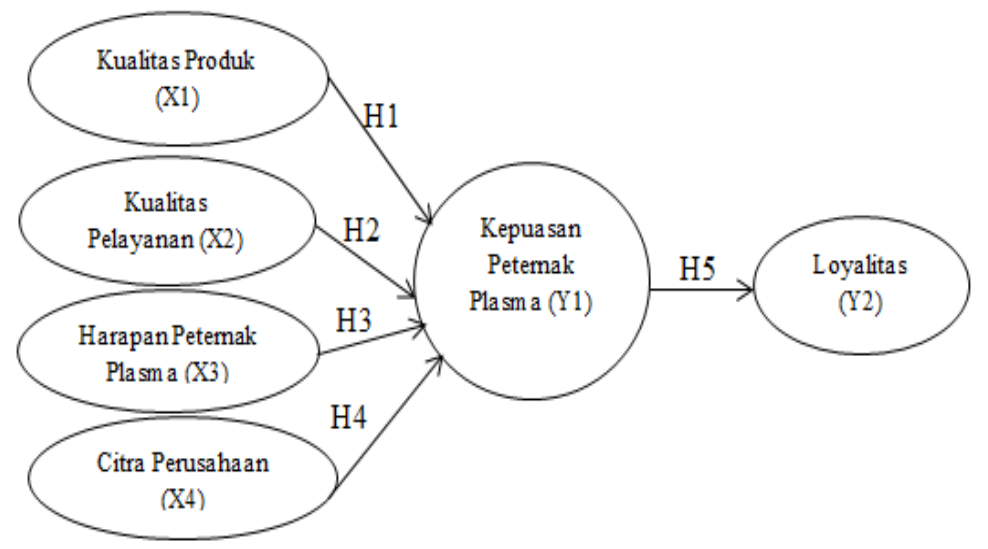

Gambar 1. Model penelitian.

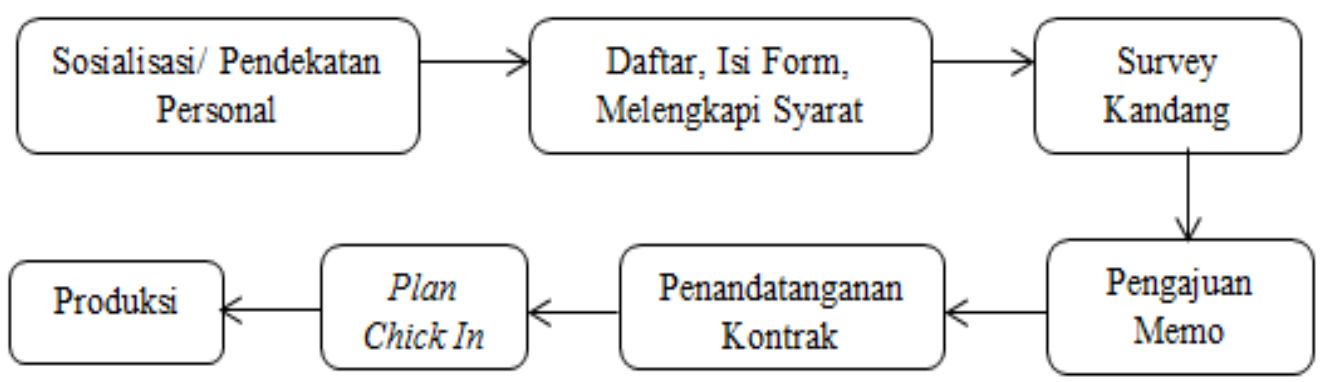

Gambar 2. Skema mekanisme pelaksanaan kemitraan. 
cabang mengajukan memo ke perusahaan pusat. Apabila perusahaan pusat telah menyetujui ajuan yang diberikan perusahaan cabang, calon peternak plasma segera menandatangani kontrak kerjasama yang telah disepakati bersama sebelumnya, yaitu perjanjian pemeliharaan ayam pedaging dengan menyertakan notaris.

Plan chick in atau pengisian kandang dengan DOC/ bibit dilakukan setelah penandatanganan perjanjian dan kandang sudah siap untuk diisi. Sebelumnya dilakukan pengiriman pakan ternak satu hari sebelum pengisian kandang. Ketika bibit sudah masuk kandang produksi ayam pedaging sudah mulai dijalankan. Secara lebih ringkas mekanisme pelaksanaan kemitraan di PT. Malindo Feedmill dapat dilihat pada gambar 2 .

\section{Pengujian Instrumen}

Instrumen penelitian dikatakan valid karena memiliki nilai loading factor lebih besar dari 0,70 dan AVE lebih dari 0,5. Berarti bahwa item pertanyaan mengukur aspek yang sama (valid). Reliabilitas instrrumen juga dikatakan tinggi karena memiliki nilai lebih dari 0,60. Sehingga, semua variabel pengukuran dapat dipercaya atau diandalkan dalam penelitian ini dan dapat dilanjutkan ke penelitian selanjutnya.

\section{Evaluasi Model Pengukuran (Outer Model)}

Evaluasi model pengukuran adalah mengukur dan mendefinisikan bagaimana setiap blok indikator berhubungan dengan variabel latennya.

1) Convergen Validity

Penilaian berdasarkan korelasi antara skor item dengan skor variabel yang dihitung dengan PLS. Model pengukuran memilliki validitas yang tinggi apabila nilai loading factor lebih besar dari 0,70 (Ghozali, 2014). Diketahui bahwa semua indikator dalam variabel laten memiliki loading factor lebih besar dari 0,70 . Hal ini menunjukkan bahwa keseluruhan indikator dapat dikatakan valid dan memiliki tingkat validitas tinggi sehingga dapat mengukur variabel latennya. Nilai loading factor dapat dilihat pada konstruksi diagram jalur hasil pemodelan PLS gambar 3.

\section{2) Discriminant Validity}

Penilaian dilakukan dengan cara membandingkan nilai square root of average variance extracted (AVE) setiap variabel dengan korelasi antar variabel lainnya dalam model. Variabel yang baik memiliki nilai AVE lebih besar dari 0,50. Diketahui bahwa semua variabel memiliki nilai AVE yang lebih besar dari 0,50. Artinya, bahwa varian dari indikator dapat dijelaskan sebanyak 50\% atau lebih.

3) Composite Reliability

Composite reliability merupakan indeks yang menunjukkan sejauh mana suatu alat ukur dapat dipercaya atau diandalkan (reliabel). Variabel dapat dinyatakan reliabel jika memiliki nilai composite reliability diatas 0,60. Diketahui bahwa nilai composite reliability untuk semua variabel lebih besar dari 0,60. Disimpukan bahwa semua variabel laten memiliki reliabilitas yang tinggi. Sehingga semua variabel pengukuran dapat dipercaya atau diandalkan dalam penelitian.

\section{Evaluasi Model Struktural (Inner Model)}

Inner model merupakan gambaran hubungan antar variabel laten berdasarkan substantive theory. Diawali dengan melihat Rsquare adjusted untuk setiap variabel laten dependen. Perubahan nilai R-square adjusted dapat digunakan untuk menilai pengaruh variable laten independen tertentu terhadap variabel laten dependen apakah mempunyai pengaruh yang substantive. Diketahui bahwa variabel dependen, yaitu kepuasan peternak dan loyalitas memiliki nilai R-square adjusted antara 0,33 sampai 0,67. Hal tersebut mengindikasikan model masuk dalam kategori moderat. Nilai R-square adjusted kepuasan peternak 0.614 berarti variabel kualitas produk, kualitas pelayanan, harapan peternak dan citra perusahaan berkontribusi terhadap kepuasan peternak sebesar $61 \%$. Nilai Rsquare adjusted loyalitas 0.624 berarti kontribusi kepuasan peternak terhadap loyalitas sebesar $62 \%$.

Hubungan antar variabel laten juga dapat dievaluasi dengan melihat Q-square predictive relevance. Apabila nilai yang didapatkan 0.02 (rendah), 0.15 (sedang) dan 0.35 (tinggi). Nilai 
dari Q-square dapat dihitung dengan perhitungan sebagai berikut :

$\mathrm{Q}^{2}=1-\left[1-(\mathrm{R} \text {-square adjusted })^{2}\right]$

Diketahui nilai variabel dependen, yaitu kepuasan peternak dan loyalitas masingmasing sebesar 0,377 dan 0,389 . Hal tersebut mengindikasikan bahwa model termasuk kedalam kategori tinggi. Dengan kata lain, model memiliki predictive relevance yang tinggi karena nilai Q-square lebih besar dari nol dan 0,35 .

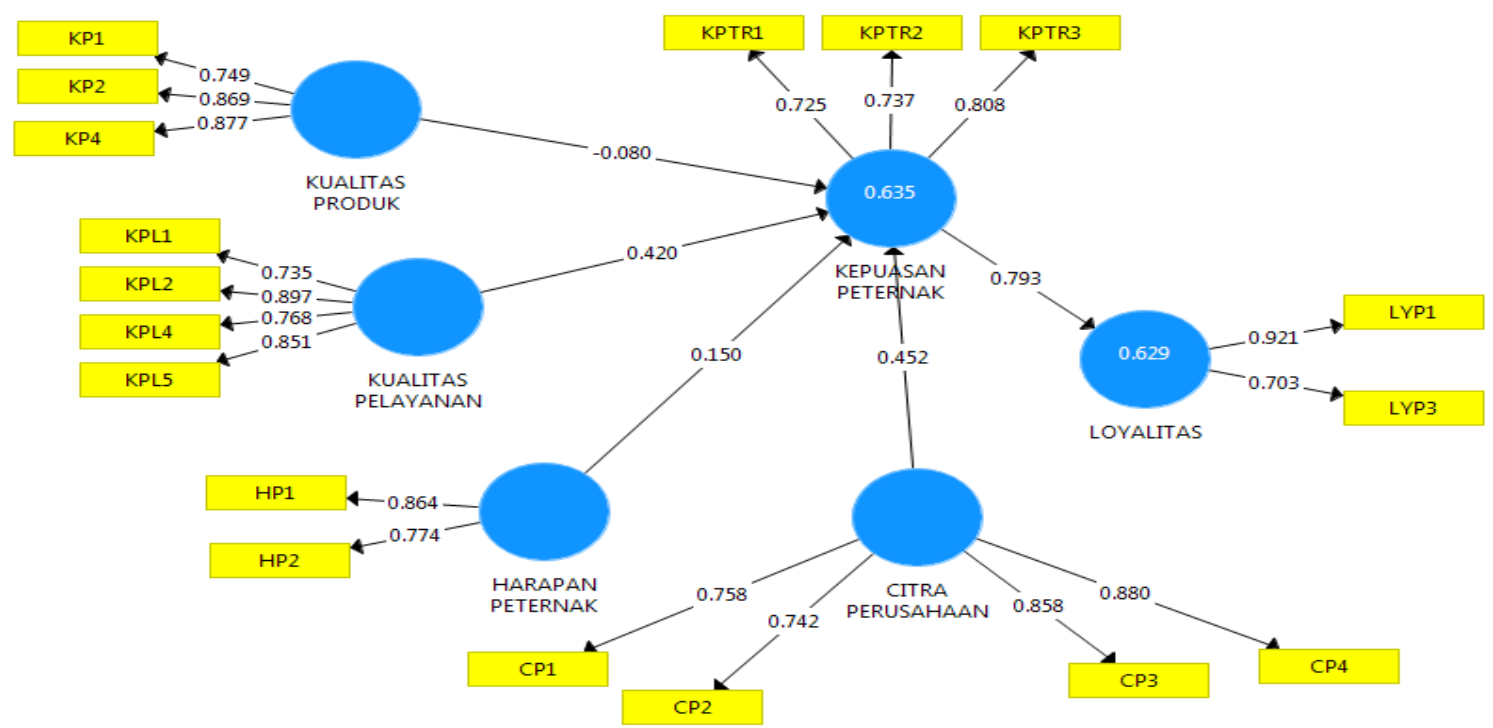

Gambar 3. Konstruksi Diagram Jalur Hasil Pemodelan PLS

\section{Hasil Bootstrapping}

Bootsrapping merupakan prosedur untuk melihat nilai koefisien jalur atau besarnya hubungan/pengaruh variabel laten. Uji hipotesis ini dilakukan dengan menganalisis nilai p-value. Apabila t-statistik lebih besar daripada t-tabel dan $\mathrm{p}$-value lebih kecil daripada $0.01,0.05$ dan 0.10 , maka hipotesis penelitian yang diajukan dinyatakan diterima. Sedangkan jika, t-statistik lebih kecil sama dengan t-tabel dan p-value lebih besar daripada $0.01,0.05$ dan 0.10, maka hipotesis penelitian yang diajukan dinyatakan ditolak.

Berdasarkan tabel 1, dapat dilihat hasil pengaruh antar variabel. Pada hasil penelitian ini, terdapat satu hubungan yang tidak signifikan yaitu pengaruh antara kualitas produk terhadap kepuasan peternak. Sedangkan, empat lainnya berpengaruh signifikan yaitu, pengaruh antara kualitas pelayanan terhadap kepuasan peternak, antara harapan peternak terhadap kepuasan peternak, antara citra perusahaan terhadap kepuasan peternak, dan antara kepuasan peternak terhadap loyalitas.

H1 : kualitas produk (X1) berpengaruh positif terhadap kepuasan peternak plasma (Y1).

Berdasarkan Tabel 1 diketahui nilai estimasi parameter sebesar -0.080 yang menunjukkan bahwa arah pengaruh kualitas produk terhadap kepuasan peternak adalah negatif. Nilai t-statistik sebesar $0.407(<1.96)$ dan p-value 0.684. Nilai ini menunjukkan bahwa nilai $p$-value tidak signifikan pada tingkat signifikansi 1\%, 5\% maupun $10 \%$, karena p-value lebih besar dari alpha. Dengan demikian hipotesis 1 yang diajukan dalam penelitian ditolak.

Pihak perusahaan selalu menjaga dan mempertahankan kualitas produk yang ditawarkan, karena hasil akan kembali ke perusahaan. Usaha yang dilakukan antara lain, selalu berkoordinasi dengan Divisi Feedmill untuk pakan ternak, melakukan pemantauan rutin DOC, memperhatikan keandalan obat dan vaksin dalam menyembuhkan dan mencegah penyakit, serta memperhatikan tingkat mor-talitas DOC dengan memeriksa kondisi DOC untuk meminimalisir mortalitas DOC, mak-simal 2\% dari populasi. PT. Malindo Feedmill tidak mem-bohongi peternak dengan kondisi DOC yang akan diberikan berdasarkan tipe DOC dan melakukan pengiriman pakan secara bertahap. Selain itu, dalam sistem kemitraan ini peternak plasma juga diwajibkan menerima produk berupa sapronak yang diberikan perusahaan inti. Hasil penelitian ini tidak mendukung hasil penelitian Wijaya (2012) yang mengemukakan bahwa, semakin berkualitas produk dan jasa 
yang diberikan, maka kepuasan yang dirasakan oleh pelanggan akan semakin tinggi.
H2 : kualitas pelayanan (X2) berpengaruh positif terhadap kepuasan peternak plasma (Y1).

Tabel 1. Hasil Bootstrapping-Path Coeffisients

\begin{tabular}{lcccc}
\hline & Original Sample & T-statistic & P-Value & Keterangan \\
\hline $\begin{array}{l}\text { Kualitas Produk } \rightarrow \text { Kepuasan } \\
\text { Peternak }\end{array}$ & -0.080 & 0.407 & 0.684 & $\begin{array}{c}\text { Non- } \\
\text { Signifikan }\end{array}$ \\
\hline $\begin{array}{l}\text { Kualitas Pelayanan } \rightarrow \\
\text { Kepuasan Peternak }\end{array}$ & 0.420 & 4.034 & $0.000^{* * *}$ & Signifikan \\
\hline $\begin{array}{l}\text { Harapan Peternak } \rightarrow \\
\text { Kepuasan Peternak }\end{array}$ & 0.150 & 1.775 & $0.077^{*}$ & Signifikan \\
\hline $\begin{array}{l}\text { Citra Perusahaan } \rightarrow \text { Kepuasan } \\
\text { Peternak }\end{array}$ & 0.452 & 2.218 & $0.027^{* *}$ & Signifikan \\
\hline $\begin{array}{l}\text { Kepuasan Peternak } \rightarrow \\
\text { Loyalitas }\end{array}$ & 0.793 & 16.319 & $0.000^{* * *}$ & Signifikan \\
\hline Cays & & & &
\end{tabular}

Catatan: $* \mathrm{p}<0,10 ; * * \mathrm{p}<0,05 ; * * * \mathrm{p}<0,01$.

Sumber: Analisis Data Primer, 2016.

Berdasarkan Tabel 1 diketahui nilai estimasi parameter sebesar 0.420 , yang menunjukkan bahwa arah pengaruh kualitas pelayanan terhadap kepuasan peternak adalah positif. Nilai t-statistik sebesar $4.034(>2,58)$ dan p-value sebesar 0,000. Nilai ini menunjukkan bahwa nilai p-value signifikan pada tingkat signifikansi 1\%, karena p-value lebih kecil dari alpha 0,01. Dengan demikian hipotesis 2 yang diajukan dalam penelitian diterima.

Peternak akan merasa puas apabila perusahaan inti memiliki kualitas pelayanan yang baik. Bentuk pelayanan yang diberikan PT. Malindo Feedmill antara lain pendampingan secara teknis maupun non-teknis dengan pemantauan budidaya oleh Technical Service dan dokter hewan secara berkala. PT. Malindo Feedmill menangani masalah yang dikeluhkan peternak dengan pendekatan langsung baik internal maupun di lapangan. PT. Malindo Feedmil juga memberikan bantuan keringanan dana usaha dengan pinjaman dana. Sistem pembagian hasil dan sistem pembayaran hasil kepada peternak plasma dilakukan berdasarkan kontrak. Untuk menjaga keamanan dan kepercayaan peternak, PT. Malindo membayarkan hasil langsung lewat rekening peternak tanpa perantara.

Kualitas pelayanan PT. Malindo Feedmill sudah dinilai baik oleh peternak plasma. Namun, masih perlu adanya peningkatan dan penambahan dalam pelayanan panen yang diberikan PT. Malindo Feedmill, diantaranya dalam menanggapi keluhan peternak akan ketepatan waktu panen dan penanganan saat panen serta meningkatkan koordinasi antar divisi produksi dan divisi panen. Hasil penelitian ini mendukung hasil penelitian Palmarudi (2012), yang menyim-pulkan bahwa beberapa atribut dimensi kualitas layanan perusahaan inti memiliki tingkat kepentingan yang tinggi.

H3 : harapan peternak plasma (X3) berpengaruh positif terhadap kepuasan peternak plasma (Y1).

Berdasarkan Tabel 1 diketahui nilai estimasi parameter sebesar 0.150, yang menunjukkan bahwa arah pengaruh harapan peternak terhadap kepuasan peternak adalah positif. Nilai t-statistik sebesar $1.775(>1,64)$ dan $p$-value sebesar 0,077. Nilai ini menunjukkan bahwa nilai $\mathrm{p}$-value signifikan pada tingkat signifikansi $10 \%$, karena p-value lebih kecil dari alpha 0,10. Dengan demikian hipotesis 3 yang diajukan dalam penelitian diterima.

Peternak plasma memiliki harapan supaya perusahaan inti dapat selalu memenuhi kebutuhan peternak dalam menjalankan budidaya produksi ternak serta memiliki harapan akan pelayanan baik. PT. Malindo Feedmill selalu berusaha memenuhi kebutuhan peternak dalam kegiatan produksi untuk menjaga kepercayaan peternak. Usaha yang dilakukan antara lain menjaga kualitas sapronak, menjaga kesehatan ayam, dan yang paling utama adalah menjaga profit peternak plasma. Hasil penelitian ini mendukung hasil penelitian Agustin, E., Fitri A., dan Rachmad, 
H. (2012) yang menyimpulkan bahwa harapan pelanggan (X3) berpengaruh positif dan signifikan terhadap loyalitas pelanggan (Y2) melalui kepuasan pelanggan (Y1).

H4 : citra perusahaan (X4) berpengaruh positif terhadap kepuasan peternak plasma (Y1).

Berdasarkan Tabel 1 diketahui nilai estimasi parameter sebesar 0.452, yang menunjukkan bahwa arah pengaruh citra perusahaan terhadap kepuasan peternak adalah positif. Nilai t-statistik sebesar $2.218(>1,96)$ dan p-value sebesar 0,027. Nilai ini menunjukkan bahwa nilai p-value signifikan pada tingkat signifikansi 5\%, karena p-value lebih kecil dari alpha 0,05. Dengan demikian hipotesis 4 yang diajukan pada penelitian diterima.

Perusahaan harus selalu mempertahankan citra baik dalam menjalankan kemitraan. Peternak akan tertarik untuk bergabung dan menjalin kerjasama dengan perusahaan apabila perusahaan dinilai memiliki image atau citra yang baik di publik. Usaha yang dilakukan PT. Malindo Feedmill dalam membangun kesan yang baik kepada peternak plasma adalah mempertahankan profit peternak selalu dalam kondisi bagus. Selain itu, support atau dukungan dari perusahaan kepada peternak juga selalu diberikan dalam mewujudkan suatu bisnis yang sehat. PT. Malindo Feedmill mengandalkan strategi win-win solution dalam menjalankan kemitraan demi kepuasan dan keuntungan bersama. Hasil penelitian ini mendukung hasil penelitian Stephen (2007), Khan (2012), dan Giovanis (2014) yang memberi hasil bahwa terdapat pengaruh positif antara citra terhadap kepuasan pelanggan.

H5 : kepuasan peternak plasma (Y1) berpengaruh positif terhadap loyalitas (Y2).

Berdasarkan Tabel 11 diketahui nilai estimasi parameter sebesar 0.793, yang menunjukkan bahwa arah pengaruh kepuasan peternak terhadap loyalitas adalah positif. Nilai t-statistik sebesar 16,319 (> 2,58) dan pvalue sebesar 0,000 . Nilai ini menunjukkan bahwa nilai $p$-value signifikan pada tingkat signifikansi $1 \%$ atau dengan tingkat kesesuaian sebesar 99\%, karena p-value lebih kecil dari alpha 0,01. Dengan demikian hipotesis 5 yang diajukan pada penelitian diterima.

Peternak plasma PT. Malindo Feedmill memiliki tingkat kepuasan yang tinggi terhadap pelayanan yang diberikan oleh perusahaan. Tingginya tingkat kepuasan peternak mempengaruhi keinginan peternak plasma untuk bertahan dan melanjutkan kemitraan dengan PT. Malindo Feedmill. Karena peternak plasma sudah memiliki loyalitas yang tinggi, maka tidak akan mudah bagi perusahaan lain untuk menarik peternak plasma PT. Malindo Feedmil untuk beralih kemitraan lain. Sebagai penghargaan kepada banyak peternak yang sudah loyal, perusahaan menyediakan liburan gratis dan mengajak peternak ke pameran-pameran peternak, serta dinner dengan pimpinan perusahaan. Peternak dengan populasi terbanyak dan kualitas yang bagus akan terpilih dari masing-masing daerah untuk mendapatkan reward. Dengan loyalitas peternak plasma, perusahaan mendapatkan keuntungan, yaitu anggota mitra semakin banyak dan dapat mengontrol kualitas perusahaan lewat keluhan peternak plasma selama bermitra.

Dalam menjalankan usaha pasti terdapat hambatan dan masalah yang dialami. Beberapa masalah yang sering muncul dalam kegiatan kemitraan ini antara lain, pengelolaan dana hasil yang terlalu lama sehingga peternak harus menunggu lama, permasalahan panen yang lama, pengiriman pakan, rugi besar, dan juga banyak peternak yang tidak memberikan data lengkap kepada perusahaan. Harapan perusaha-an untuk kemitraan dan menjaga loyalitas peternak adalah diharapkan adanya kerjasama yang baik dari kedua belah pihak yaitu perusahaan dan peternak plasma, dan juga supaya harga pasar dapat stabil sehingga tidak terjadi gejolak di pihak peternak dan masalah sosial dapat berkurang, baik internal maupun kelompok. Hasil penelitian ini mendukung hasil penelitian Rachmawati (2010) yang me-nunjukkan hubungan positif antara kepuasaan dengan loyalitas.

\section{KESIMPULAN}

1. Sistem kemitraan yang telah berjalan antara PT. Malindo Feedmill dengan peternak plasma adalah sistem kemitraan dengan pola inti plasma. Perusahaan sebagai inti dan peternak sebagai plasma. Dalam menjalankan kemitraan PT. Malindo Feedmill menggunakan strategi 'win-win solution', sehingga tidak ada pihak yang merasa dirugikan. Peternak yang ingin menjadi mitra harus memenuhi beberapa syarat 
yang dibuat oleh perusahaan. Namun, syarat yang diberikan tidak bersifat mutlak karena perusahaan banyak memberikan keringanan sebagai bantuan untuk peternak. Dalam menjalankan kemitraan juga masih sering terdapat masalah, diantaranya pengelolaan dana hasil yang terlalu lama, panen yang lama, pengiriman pakan, rugi besar, dan banyak peternak yang tidak memberikan data lengkap kepada perusahaan.

2. Kualitas produk tidak berpengaruh terhadap kepuasan peternak. Artinya, dengan semakin meningkatnya kualitas produk PT. Malindo Feedmill tidak berpengaruh terhadap kepuasan peternak plasma.

3. Kualitas pelayanan berpengaruh positif terhadap kepuasan peternak. Semakin baik kualitas pelayanan yang diberikan PT. Malindo Feedmill akan meningkatkan kepuasan peternak plasma dalam bermitra.

4. Harapan peternak berpengaruh positif terhadap kepuasan peternak. Semakin terpenuhi harapan peternak plasma maka akan menambah tingkat kepuasan peternak dalam bermitra.

5. Citra perusahaan berpengaruh positif terhadap kepuasan peternak. Semakin baik citra dari perusahaan inti, maka akan semakin tinggi tingkat kepuasan peternak plasma dalam bermitra.

6. Kepuasan peternak berpengaruh positif terhadap loyalitas peternak. Semakin tinggi tingkat kepuasan peternak plasma akan meningkatkan loyalitas peternak plasma.

\section{DAFTAR PUSTAKA}

Agustin, E., Fitri A., dan Rachmad, H. (2012). Analisis pengaruh harga produk, kualitas produk, harapan pelanggan dan citra merek terhadap loyalitas pelanggan melalui kepuasan pelanggan produk laptop Accer. Jurnal Teknik Industri.

Badan Pusat Statistik. 2014. Daerah Istimewa Yogyakarta dalam angka. http://perpustakaan.bappenas.go.id/.

Diakses pada 26 Oktober 2015.

Gh0zali, I. 2014. Structural Equation Modeling Metode Alternatif dengan Partial Least Squares (PLS). Semarang: Badan Penerbit Universitas Diponegoro.

Ghozali, I. 2008. Structural Equation Modeling Metode Alternatif dengan
Partial Least Square, Edisi 2. Semarang (ID): Badan Penerbit Universitas Diponegoro.

Giovanis, A. N. Dimitris Z., Petros, T. 2014. The antecedents of customer loyalty for broadband services: the role of service quality, emotional satisfaction and corporate image. Procedia, Social and Behavioral Sciences 148 ( 2014 ) 236 244.

Khan, S., Hussain, S. M., Yaqoob, F. 2012. Determinants of customer satisfacti on in fast food industry, International Journal of Management and Strategy, Vol. 3.

Palmarudi, K. Kasim. 2012. Analisis tingkat kepuasan peternak dalam pelaksanaan kemitraan usaha peternakan ayam ras pedaging di Sulawesi Selatan : studi kasus di Kabupaten Maros (Analysis on satisfaction level of broiler chicken farmer in implementing business partnership in South Sulawesi: A case study in Maros Regency). JITP, Vol. 2 No.1.

Priyono, B.S, N. Nufus, dan K. Dessy, 2004. performans pelaksanaan kemitraan PT. Primatama Karya persada dengan peternak ayam ras pedaging di Kota Bengkulu. Jurnal Ilmu-Ilmu Pertanian Indonesia, Vol 6, No.2, hal: 111-115.

Rachmawati, R. 2010. Pengaruh kepuasan terhadap loyalitas pelanggan (sebuah kajian terhadap bisnis makanan). TEKNUBUGA, Volume 2 No. 2.

Sanusi, A. 2011. Metodologi Penelitian Bisnis. Jakarta: Salemba Empat.

Stephen L. Sondoh Jr, Maznah Wan Omar, Nabsiah Abdul Wahid, Ishak Ismail, and Amran Harun, 2007. The effect of brand image on overall satisfaction and loyalty intention in the context of color cosmetic, Asian Academy of Management Journal, Vol 12 (83-107).

Wijaya, H., Bunasor S., Bonar M. S. 2012. Kepuasan peternak mitra terhadap kemitraan model contract farming usaha ternak broiler di Provinsi Jawa Barat dan Banten. Jurnal Manajemen \& Agribisnis, Vol. 9 No. 2. 